\title{
Voicing Darfour's Hu (Wo)man Memory: Tears of the Desert through World Literature and Collaborative Translation Grid
}

\section{Riham Debian}

Institute of Applied Linguistics and Translation, Alexandria University, Egypt

Received: 29 Sept 2020; Received in revised form: 19 Nov 2020; Accepted: 23 Nov 2020; Available online: 03 Dec 2020

C2020 The Author(s). Published by Infogain Publication. This is an open access article under the CC BY license

(https://creativecommons.org/licenses/by/4.0/).

\begin{abstract}
This paper tackles the question of voice retrieval of the Sudanese Subaltern experiences through the authorship/co-authorship of White British male subject, and the implication for collaborative translation into world literature. The paper particularly engages with the questions of whose voice and whose authorship in translating and worlding minority subaltern literature, in the context of the metropolitan powers' appropriating politics, and the selective access and humanitarianism of Anglo-American (international) publishing industry. Adopting an interdisciplinary approach, the paper instrumentalizes the sociological turn in Translation Studies (2010) and Dambroush's take on World Literature (2003) to read the socio-political implication of the production and circulation of Bashir and Lewis' Tear of the Desert: a Memoir of Survival in Darfur(2008) to the English-speaking readership. The paper specifically examines the conceptual and textual grid (Lefevere 1999) and their underlying ideology through a tri-fold relational scheme: first, the relation between the text and its author, specifically the question of Bashir's voice in the text; second, the relation between the author and coauthor/collaborative translator(S); and third, the relation between the co-author and South-ridden conflict zone. The paper seeks to investigate the political implication of worlding war literature-through peace journalism (Lynch 1997)_for international readership and politics. The paper argues for the following. First, the textual grid of Tears of the Desert (2008) invokes Morrison's aesthetic poetics of re-memory (Morrison 1988), which takes shape through instrumentalization of the motherhood trope and intergenerational relaying of past memories to work out the meaning of the present. Second is the conceptual reworking of the text in accordance with the ideology of the interlocutor, and the resultant silences and appropriation of the object of interlocution within the horizon of expectation of international readership. Third is the impact of interlocution on the frames in which the text is positioned and through which it garners visibility and acclaim. Finally, the paper argues for opening theoretical repertoire between translation, literature and peace journalism to discern the political and poetical frames for composing the other and the enabling access structures for the subaltern visibility (not voice) within hegemonic discourse.
\end{abstract}

Keywords-World Literature, Collaborative translation, Conceptual and Textual Grids, Subaltern's Voice and Visibility.

\section{INTRODUCTION}

The subaltern cannot speak. There is no virtue in global laundry lists with women as a pious item. Representation has not withered away. The female intellectual as an intellectual has circumscribed stake which she must not disown with a flourish (Spivak 1988, p.104)

"USE A SLAVE TO KILL A SLAVE" (Bashir

ISSN: 2456-7620 
Critiqued for her verdict, Spivak's take on the inaptitude of the subaltern to speak is tied up with the question of representation power politics. Representation power politics sets a hierarchal subject-object relation between representerrepresented and representativeness with women of color as the par excellence object of representation in national and international patriarchal discourse and feminisms. Accordingly, for Spivak the task of the female intellectual activist is to dismantle subalternity through unpacking the power-grid of its constitution and the global laundry list that keeps it in tow. This becomes the female intellectual's circumscribed stake that trespasses the seemingly innocuous politics of "[giving] the subaltern voice"(Spivak 1988, p. 106). The latter's position simultaneously reiterates the colonialist scheme embedded in the British dictate on the sati, where 'white men saved brown women from brown men', and enacts the post-colonial subject-position conservation of Western selves and knowledge on Third World women. As Spivak puts it, the subaltern cannot speak because speech:

does not exist in the subaltern's sphere ... speech is produced by inserting the subaltern into the circuit of hegemony ...to work for the subaltern, means to bring it into speech ... you don't give the subaltern voice. You work for the bloody subaltern; you work against subalternity ... [outside] the hegemonic discourse (De Kock 1992, p. 46)

As such, the prerequisite for speech activation and circulation is the subaltern insertion into the circuit of hegemony, which provides for access structure to enabling the hearing of voice and its translation into presence in accordance with the power grid. The latter is not working against subalternity, rather working within the hegemonic discourse to keep the subaltern in place and power politics intact where 'white man protects brown women from brown men' and thence the instrumentalization of the slave to kill the other slaves.

Inserted into the circuit of hegemony, Tears of the Desert: $A$ Memoir of Survival in Darfur (2008) places Darfur's $\mathrm{Hu}$ (Wo)man crisis in the speech sphere through the authorshipco-authorship of Halima Bashir and Damien Lewis. The latter, not quite Spivak's female intellectual activist, is a British male military journalist-turned writer, whose career trajectory in war/peace journalism provided for the access structure to enabling the hearing of the subaltern Sudanese voices and the translation of their crisis into visibility. In fact, this particularity of Lewis' gender identity and metropolitan affiliations bring to the fore Spivak's dual formulation for the problematics of Western self's subject-position conservation

ISSN: 2456-7620 and the subsequent objectification of the subaltern voice through the innocuous politics of giving her voice. More specifically, Lewis subject-position (its underlying enabling access structure) provides a case in point for the embeddedness of poetics in politics and the political instrumentalization of the Subaltern's voice retrieval and translation for the furthering of the metropolitan control scheme. The latter is enacted through the cultural translation and worlding of the Sudanese subaltern post-colonial experience into English along the frames of world literature.

\subsection{Methodology and Argument}

This paper investigates the problematics of the implication of post-colonial poetics in metropolitan politics, and the political instrumentalization of worlding and translating subaltern voices into English through the frames of world literature. The paper tackles the following questions: first, the question of the authorship/co-authorship of White British male subject of Sudanese subaltern experiences and its implication for voice retrieval and representation power politics(whose voice and whose authorship); second, the poetics of the subaltern's insertion in the circuit of hegemony through the collaborative translation into world literature. Third, the paper deals with the questions of the political end of subaltern voice retrieval and worlding minority subaltern literature in the context of the metropolitan power appropriating politics and the selective access and humanitarianism of Anglo-American (international) publishing industry. Adopting an interdisciplinary approach, the paper instrumentalizes the sociological turn in Translation Studies (2010), specifically the sociological relational approach of Collaborative Translation (Cordingley. Manning 2014) and Dambroush's take on World Literature (2003) to read the socio-political implication of the production and circulation of Bashir and Lewis' Tear of the Desert: A Memoir of Survival in Darfur (2008) to English-speaking readership. The paper employs a mode of "distant reading" (Moretti 2000) that combines social and textual analysis. The latter are administered through analyzing the linguistic, paralinguistic and extra textual frames in which the text is wrapped and warped for international readership. The aim is to discern the molding systems that shape the textual poetics and propels its metropolitan politics - despite the avowed dissent postcolonial politics. The paper-end is to engage with what Wolf identifies as the "transnational translational process" (Wolf 2009) of circulation and politicized representation embedded in World Literature, and thence the political 
functionality for packaging Darfour's human and womencentered crisis for international readership and politics.

The data collection and procedural analytical scheme of the paper is theoretically premised on the notion of intertextuality that is operationalized through cross reading the text against/through the context of production and the author/coauthor extratextual discursive practices and political activism in print, virtual and digital media sphere. Accordingly, the paper examines the memoir's conceptual and textual grid (Lefevere 1999) and their underlying ideology ${ }^{i}$ through trifold relational scheme. First is the relationship between the text and its author, specifically the question of Bashir's voice in the text. Second is the relation between the author and coauthor/collaborative translator(S). The focus is on Lewis and the question of whose voice or rather how much of his voice, given the text language of delivery-English. Third is the relation between the co-author and South-ridden conflict zone, his discursively constructed identity in the digital sphere and peace/military journalistic activism (Lynch 1997) and the political implication of worlding world literature for international readership and politics. Lewis has co-authored Tears of the Desert (2008) after his earlier co-authorship of the subaltern story of Mende Nazer in Nuba MountainsSlave: My True Story (2004).

The paper argues for the following. First, the textual grid of Tears of the Desert (2008) invokes Morrison's aesthetic poetics of re-memory (Morrison 1988), which takes shape through instrumentalization of the motherhood trope and intergenerational relaying of past memories to work out the meaning of the present. Second is the conceptual reworking of the text in accordance with the conceptual grid (ideology) of the interlocutor and the resultant silences and appropriation of the object of interlocution within the horizon of expectation of international readership. Bashir's representational identity politics is composed along separatist poetics that speaks of pro-Western and Anti-Arab ideological stance in opposition to the African identity-strand. African identity grid figures as the enabling conceptual framework for voice access and translational transnational circulation. Third is the impact of interlocution on the frames in which the text is positioned and through which it garners visibility and acclaim. Finally, the paper argues for opening theoretical repertoire between translation, world literature and peace journalism to discern the political and poetical frames for composing the other and the enabling access structures for the subaltern visibility within hegemonic discourse. Ultimately, the paper poses a query on the aptitude of the subaltern to fully unspeak the "unspeakable thoughts, unspoken" (Bhabha 1997 p.446) outside the power dynamics of global politics and the mould of world literature. According to Tally Jr, despite its avowed dissent and postcolonial overture, world literature poses as "a marketing genre, a commodified and easily consumed product for which 'exotic' is merely an advertising label" (Tally Jr. 2014, p.414).

\section{COMPOSING THE OTHER: SOCIOLOGICAL TURN IN TRANSLATION AND WORLD LITERATURE STUDIES}

Precursor of the sociological turn in TS, Lefevere's take on cultural translation and the socio-political functioning of translated text in host societies (1992) initially brought forth his thesis on translation as refracted re-writing. The latter is conducted in accordance with the cultural script of a given society and the power-dynamics of accommodation and cooptation in the context of the Anglo-Saxon importation of foreign cultural artifact. These preliminary insights into the power-political poetics of cultural translation were later developed in Lefevere's postcolonial paradigm for cultural translational production and circulation (1999). In Postcolonial translation: Theory and Practice (Bassnett 1999), Lefevere challenges "the supposedly primary or fundamental role played by linguistic codes in the operation known as "translating" (Lefevere 1999, p,74). Lefevere provides for an application framework for decoding the thinking process underlying the translators' opting for "Composing the other" along the dual grid levels (1999). These dual grids are the textual and conceptual grids. The former constitutes "markers designed to elicit certain reactions on the reader's part" (Lefevere 1999, p. 76). The latter is "the conceptual position" (Lefevere 1999, p. 92) and ideological stance formulated through the set of "opinions and attitudes deemed acceptable in a certain society at a certain time, and through which readers and translators approach text" (qtd. from Hermans, 2004, p. 127). Lefevere premises the communication and circulation(canonization) of translated text on the working of the intertwined grids on the translators' choices. The latter set their creative composition of the cultural other through the metropolitan categories, especially in the context of Anglo-American Western cultures, which “'translated' (and 'translate')non-Western cultures into Western categories to be able to come to an understanding of them and, therefore, to come to terms with them" (Lefevere 1999, p. 78). 
Lefevere's bid for circulation and refraction resonates with Dambroush's definition of World Literature ${ }^{\mathrm{ii}}$ (2003). According to Hawas and Theo D'haen's formulation, World Literature codifies "the process of translation, circulation, and re-interpretation ... [where] language is a temporary mode, and a text is always a potential work-in translation" (Hawas. Theo D'haen 2017, p. 273). Dambroush proposes a threefold definition of World Literature "focused on the world, the text, and the reader":

1. World literature is an elliptical refraction of national literatures.

2. World literature is writing that gains in translation.

3. World literature is not a set canon of texts but a mode of reading: form of detached engagement with worlds beyond our own place and time. (Dambroush 2003 p. 290)

As such, World Literature, like translation, problematizes the sui generis agency of the writer and translator to bring to the fore the circulation premises and its underlying questions of access structures. The latter transcend the issue of the linguistic paradigm onto the collaborative overture of the production and communication processes. This collaborative dimension is the investigation object of the burgeoning sociological turn in translation and literary studies. Contemporary scholarship in literary and translation studies investigate "the embeddedness of authorship in social structures" and "the nexus at which the power and influence of different networks and agents intersect, as well as 'the social discursive practices which mould the translation process and which decisively affect the strategies of a text to be translated' (Corrodingly. Manning 2014, p. 14). Hence, from the perspective of relational sociology to literature and translation, the questions become in Wolf's formulation, "Who translates what, for which purpose, with which strategies? (Wolf 2009, p.77). In the case of Tears of the Desert (2008), these questions assume a prime significance on two grounds: first, the intertwined working of the textual and conceptual grid in the compositional construction of the other, underpinned as it is by a dual othering structures, namely race and gender; second, the enabling politics of construction and circulation of African Sudanese subaltern identity frame, administered through the intertextual instrumentalization of Afro-American women writing poetics.

\subsection{Tears of the Desert:}

ISSN: $2456-7620$

https://dx.doi.org/10.22161/ijels.56.29

\section{Textual-Conceptual Grids and Subaltern's Unspeaking} the Unspeakable.

Tears of the Desert (2008) is composed along the textual grid of Afro-American women literature through a strategic deployment of the motherhood trope. The text opens on a lullaby sung by Bashir to her cuddled baby boy in their London flat, after she has taken a political asylum in Britain. This textual opening provides an entrée into the transnational African suffering through a tactful employment of the resistant oppositional mould ofre-memoryii (Morrison 1987, 1989, 2019).According to Hirsch's reading, re-memory is structured in Afro-American scheme "as a ground of resistance and opposition ... [through] finding a way to remember, and to do so differently, what an entire culture has been trying to repress" (Hirsch 1994 p. 97). It provides for the venue for subsequent intergenerational relaying of memories to work out the meaning of the present.

Invoking the oppositional poetics of re-memory, Bashir's opening lullaby triggers off the memory of her mother and grandmother, Suma, and inaugurates her mental and psychological transposition in time and place:

I am in Africa again in the loving warmth and security of my family ... with my tribe again, the Zaghawa, a fierce, warlike black African people ... in my home, with my family, with my people, in my village, in Darfur. (Bashir 2008, p. 12)

This aesthetic entry aligns the textual grid with the AfroAmerican women poetics of re-memory, yet with alternative political ploy-illuminated through the interjection of mainstream poetics. Bashir's mental and psychological transposition sets the reminiscence off to her gang-rape account at the hand of the Sudanese security state, and the narrative off to the auto bio graphical mainstream telling scheme

\section{Come here my love,}

I have a story for you

MY NAME IS Halima. It is an important name, and you must remember it. It is important because my father gave it to me seven days after I was born, in the village naming ceremony. In a sense my father saw into the future, for he named me after who and what I was to become (Bashir 2008, p. 16) 
According to Hirsch(1994), the poetics of re-memory is played out through the compound effect of repetition and memory: "repetition + memory, not simply a recollection of the past but its return, its re-presentation, its re-incarnation, and thereby the re-vision of memory" (Hirsch 1994 p.107). As such, the poetics of re-memory deviate from the mainstream chronological telling that reiterates the masculine myth of organized complete self.

However, despite the initial ploy to re-memory poetics and politics, Bashir's textual form fits what Hirsch (1994) would qualify as 'recollection of the past' with the narrative organized in a relatively chronological order. The individual "I" is positioned at the center in a progressive linear scheme of the Self's success-story. Halima self-story is relayed along masculine self-congratulatory scheme that stands at odds with her positioning and constructs the odds of her Darfurian positioning vis-à-vis the Sudanese Arab identity. The odds of her positioning are conceptually framed around both the metaphor of 'the desert' as the topographical icon of her local geographical identity category, and the binary oppositional categories of Arab Sudanese versus African Zaghawa labeling category.

\subsection{Conceptual Grid and Representational Binary Identity-Politics}

The text is divided into four parts: Child of the Desert, School of the Desert, Desert of Fire, Desert of No Return fire. It is conceptually framed along two metaphors: the metaphor of the 'desert', the semantic content of which involves harshness, light, fire, aridity, exoticism...etc.; and the metaphor of tears-evoking suffering trauma, femininity and the quenching of fire. This conceptual titular framing, with fire as a centerpiece, provides for tactile inversion and tacit exoneration of Heart of Darkness' "The horror! the horror!" (Conrad 1899, p.145). It transposes Western guilt on their Arab counterpart, and feed into the oppositional binaries of Arab versus African, around which Bashir's representational identity politics is constructed. A semantic analysis of the conceptual metaphorical frames would read as follows: Tears cleanse the Heart through quenching the Desert-like hollowness of 'the horror!'. The latter is the fire of guilt of the Western colonialist self that should be quenched through identifying a third party and transposing the Darkness onto the Arab. The designated outcome is absolving the legacy of Western horror-centric colonial enterprise and complicity in the postcolonial world politics, and the subject-conversion of Western White Man's Mission-Burden. The structural parallelism between the unspoken-of-yet conceptually

ISSN: 2456-7620

https://dx.doi.org/10.22161/ijels.56.29 invoked Heart of Darkness (Conrad 1899) and Tears of the Desert (2008) is further elaborated through the constructed oppositional binaries of Bashir's in-group identity. (Fig 1)

With 'desert', 'fire' and 'darkness' come the" "the lightskinned Arab", "the nomadic Arab tribes from the desert", "the Ahrao - a word that for us signifies the Arab enemy." (Bashir 2008, p. 97). The "Ahrao", a dehumanized abstracted category that Halima loathes, becomes the centerpiece of her school days' exposition with the teachers "a mixture of Arab and black African" and the good girls 'African', bad girls 'Arab' speaking Arabic. Arabic, the language of the enemy, is "a language that was alien to my tribe" (Bashir. p. 104) despite going to the Imam every Friday to "to memorize verses of the Koran" (Bahir p. 127) and despite her father's ownership of a radio and T.V. sets that spoke in Arabic. The narrative spans the period 1978-2008; Sudan began Arabicization as cultural policy in 1964 taking it to a higher level in 1999 revolution in higher education (Nur 2014)

In comparison to Arabic, English was "world-wise and superior" (Bashir 185). The Khawajat (Westerners) has "skin so white it looked like butter ... were said to be good people. They lived out in the bush where they dug wells and built schools for the Zaghawa villagers" (Bashir 425).The emissaries of light doing charitable work for her tribe, English becomes her favorite subject taught by an Arab teacher that she did not so much like because "the best homes and the best jobs were reserved for [the Arabs]?" (Bashir, p. 183). Excelling at school, she beats the Arab girls and enters Medical school to graduate as a medical rebel doctor, who is hunted down by the regime on account of treating Zaghawa was and speaking out against programmed rape for Africans. Halima is subjected to gang-rape and flees to her village. Her father marries her off to a distant cousin. She seeks political asylum in the UK, where she needs an interpreter because her "English was pretty basic" (Bashir, p. 479).

\subsection{Frames: Language Packaging as Enabling Circulation Structures}

With her 'pretty basic English', Bashir co-authors a book with pretty much flawless English peppered with Culturally Specific Items (CSI) - allocated to the glossary. Part of contemporary textual norms of translated and minority literature, the presence CSI glossary structures the narrative cultural specificities and markets its exotic content. The glossary aesthetically functions as a marketing ploy and a poetic testament to the worldliness of its literature and the humanism of its interlocutor. The latter feature becomes 
particularly salient considering the enabling frames, in which Bashir's account is packaged to be offered to the publishing industry for consumption.

Bashir's account is constructed along four frames with assertive omission of the national dimension. First is the individual frame. Bashir's life-story is constructed along a developmental chronological pattern with the 'I' at the center-despite initial foregrounding of maternity and relationally. The central presence of the 'I' in the narrative aesthetically contradict with the circularity and fissures of trauma literature. Second is the regional frame. This frame assumes a primacy as a marketing strategy for the exotic, which the text hones to perfection through the elaborate articulation of tribal identity-politics and in-group identity representation in opposition to the colonialist Arabs. Third is the global frame - enacted through the conceptual grid of the book. The book message and underlying politics is a plea for White Man's Mission-Burden enactment (hence its redemption) through saving black-skinned Zaghawa was from brown-skinned colonialist Arabs. The linguistic omission of the national frame is conceptually substituted for through the ideological invocation of the holocaust frame.

\subsection{Holocaust Frame: Book-Covers Packaging of Bashir's story and Darfur's Crisis.}

Bashir's book is available in more than one edition and different book covering, whose conceptual framing and ideological wrapping pay homage to the Holocaust frame both in language and imaging. The first book cover verbally constructs the account in terms of "One woman's true story of surviving the horrors of Darfur"(Fig 2) The lexis 'horror', at the centerpiece, provides a scheme for framing her story within both the conceptual grid of Heat of Darkness and Holocaust frame. The word "horror" is directly referenced in Bashir's account on her public speech in the Holocaust Memorial Museum in London and keeps recurring in other book covers. The holocaust framing of her account is further substantiated through the drawn analogy between Bashir and Anne Frank. The tag line of the second book cover(Fig 3) is "Darfur has found its Anne Frank", a line that features as a testimonial from Tim Butcher in his authorial capacity as the author of Blood River: A Journey to African Broken Heart $(2010)^{\text {iv }}$. The direct referencing of Halima Bashir as the newly found Anna Frank of Darfur poses as an overt conceptual grid through which Darfur regional crisis is packaged for circulation and consumption within the holocaust narrative scheme. In the Anglo-American cultural industry, the invocation of the holocaust frame for non-Western nation-

ISSN: 2456-7620 states has been instrumentalized in Zeinab al-Ghazali's packaging (Debian 2017) and the Syrian Aleppo crisis (Debian 2019). The political ramification of the holocaust frame invocation in both cases (Egypt and Syria) was designed to enlist a public opinion consensus on the humanitarian inevitability of national regime-change administered through Western humanitarian-military intervention. The latter has been charted to tune in with Anglo-American imperialistic scheme for the new world order through cultural diplomacy and policy architecting of a new Middle East (Debian 2017; 2019).

\section{WHITE MAN'S MISSION-BURDEN REDEFINED}

\section{"Use a Slave to Kill a Slave" and the Power Dynamics of Interlocution and Collaboration}

The horror/holocaust frames and their consequential conceptual packaging not just provide for the enabling structures for the text communication and circulation. They more importantly figure as the site for simultaneously redefining the White Man's Mission-Burden and configuring the idea behind the neo-conquest of the Earth through collaborative writing/translation. A cultural diplomacy tactic for guilt transposition and redemption, collaborative writing and cultural translation becomes the policy enactment of the dictum of 'use a slave to kill a slave that underlies the powerdynamics of interlocution and giving the subaltern voice. A Sudanese proverb proroguing Tears of the Desert (2008), "use a slave to kill a slave" poetically functions as a formalistic token to the text cultural specificity that unwittingly be-tells of the ideological scheme behind the translation event as much as the tactic of its implementation. This becomes particularly evident in the context of the power dynamics of interlocution and the social habitat of collaboration.

Asylum seeker in the UK, Bashir was initially located in asylum hostel until re-united with her husband, who had earlier fled to the UK on account of state-security hunt down. Without a formal legal status, they were denied asylum claim and were about to be deported to Sudan when she was approached Aegises Trust to tell her story of rape and suffering. Her story garnered enough interest to make it to the BBC. This in turn provided the couple for enough security against the impending threat of deportation. According to Bashir, "My face became the face of suffering in Darfur, as newspapers across the world carried full-page advertisements decrying the rape of women in my homeland" (Bashir, p. 
520).With "a media profile [giving her] a little bit of power" (Bashir, p. 524), Bashir saved her husband from an impending deportation and was approached by Damien Lewis, a white male British former war reporter to tell her story on Darfur. Bashir won her case against deportation. She was granted asylum/refugee status in the UK three months after the writing of the book, largely due to the identity of her interlocutor.

Lewis' fame and expertise in war/peace news reporting garnered him a place in literary circles. His authorial identity for Bashir's memoir provided for Bashir's niche in world literature and politics. Bashir is currently framed in international media as "human rights activist from Darfur". She is a staunch supporter for the ICC verdict on President Bashir's charges for genocide. She had been granted entry in the Oval Office of the White house in December 2008-four months after the publication of her book ${ }^{\mathrm{v}}$.

\subsection{Habitus: Damien Lewis' Interlocutor/-tion and the Dynamics of Institutionalized Cultural Capital}

In Bourdieu's scheme (1986), habitus references the physical embodiment of cultural capital in its triad forms: embodied (cultural finesse), objectified (material riches), and institutionalized (credentials). As Bourdieu states:

the embodied state, i.e., in the form of long-lasting dispositions of the mind and body; in the objectified state, in the form of cultural goods (pictures, books, dictionaries, instruments, machines, etc.), which are the trace or realization of theories or critiques of these theories, problematics, etc.; and in the institutionalized state, a form of objectification which must be set apart because, as will be seen in the case of educational qualifications, it confers entirely original properties on the cultural capital which it is presumed to guarantee (Bourdieu 1986).

Qualifying Marx and transposing capital within the symbolic order of culture, cultural capital in Bourdieu's scheme figures as the source of social inequality and power-politics. At the end of the day, cultural capital "is convertible, on certain conditions, into economic capital and may be institutionalized in the forms of educational qualifications ... institutionalized in the forms of a title of nobility" (Bourdieu 1986). It features as a mechanism of power dynamics providing for authority and access structure to instiutionalized and hierarchy ridden power structure of the system world.

Lewis' instiutionalized credentials and media structured cultural capital provide Bashir with an entry gate for

ISSN: $2456-7620$

https://dx.doi.org/10.22161/ijels.56.29 circulation and canonization. They also showcase the power dynamics of interlocution and retrieval of the subaltern voice through the authorial weight and positioning of the interlocutor.

The text back-cover positions Lewis as an endorsement to the veracity of Bashir's account with the section on the author allocating one line to Bashir and five-line paragraph to Lewis.
About the Author
Halima Bashir lives with her husband and son in England, where she continues to speak out about the violence in Sudan.
Damien Lewis has spent the last twenty years reporting from war zones in Africa, with a particular focus and expertise in Sudan. His reporting from Darfur won the BBC One World Award. He is the internationally bestselling co- author of Slave, winner of the Index on Censorship Book Award. (Bahir, back-cover)

Lewis's endorsement positioning and authorial weight is not without reason. A darling of military social media websites, Lewis figures in military blogs in the testimonial section under the title of "Military: Real Heroes, Real Stories-in their own words" (http://www.militaryspeakers.co.uk/speakers/damien-lewis). His authorial identity is framed in line with his expertise in military soft power operation ${ }^{\text {vi }}$ :

Damien Lewis is the award-winning author of a number of bestselling books on elite military operations. He specializes in producing popular stories, focusing on a small group of soldiers and their missions. His books have a wide public appeal and are published in over 30 languages. His military non-fiction works Operation Certain Death, Apache Dawn and Fire Strike 7/9 are Sunday Times bestsellers. Damien's diverse portfolio of successful work is testament to his eloquence and his leading military knowledge, a skill set that makes him an exceptional speaker. His understanding of military and civilian environments means he can understand how the former can enhance and help the latter. (http://www.militaryspeakers.co.uk/speakers/da $\underline{\text { mien-lewis) }}$

Coming to literature from journalism, Lewis garnered literary fame particularly because of her military socio-cultural expertise in the field of war and conflict news reporting in the 
global South and his cultural habituation in non-Western world. This institutionalized form of cultural capital has been academically codified in terms of peace-journalism (Lynch. 2015). Its origin and object of study are located in war journalism. Its set agenda is creating an ethical paradigm for news reporting in conflict zone, based on the scheme of conflict dialogic resolution. Its methodological scheme deviates from mainstream claim to objectivity through storytelling attuned to the balance between the different parties in a conflict and with ethical responsibility to avoid partisan demonization of one against the other. Its theoretical scheme takes hue from discourse analysis and the effect of the linguistic framing on the socio-cognitive perception of conflict. Its practice encourages creative input on part of journalists to avoid the impasse created from binary-power politics. Lynch defines peace journalism in the following terms:

Peace Journalism is when editors and reporters make choices - of what to report and how to report it - that create opportunities for society at large to consider and value nonviolent responses to conflict. (Lynch 2015, p. 193)

In the "Peace Journalism Option" (1997) ${ }^{\mathrm{vii}}$, Lynch's stress on journalists' choice and conditioned partiality (attuned to creative creation of dialogue to enhance non-violent responses) become the centerpiece of an imagined journalistic practice. This imagined practice steers away from demonizing conflict parties through attention and illumination of the preconflict historical leanings.

Not quite the peace journalist, Lewis writing on and voicing of African subaltern Sudanese women in the case of Bashir and Nazer neither takes on the historical dimension of the postcolonial conflict, nor steers away from demonization of power politics. Rather, in line with his military-centric cultural capital and military-shaped ideological operation, Lewis tactfully composes their subaltern identities within a militarized centric world-picture. Through their textual composition and construction as the other of Sudanese national regime, Lewis instrumentalizes their subalternity to avert unspeaking the global power-politics. Speaking up the likely to-be spoken-of the demonization of the brown male other, Lewis enables composition and circulation in accordance to the humanitarian cosmetic veneer of the military-centered global world order and within the circuit of hegemonic discourse of white man's saving mission for brown women.

ISSN : 2456-7620

https://dx.doi.org/10.22161/ijels.56.29
In "A Victim's Point of View", a column published in the volume International Justice: Pragmatism or Principle, Lewis recounts his encounter with Nazer and Bashir and the collaborative authorship of their stories. Focusing on Bashir, Lewis allocates a large part of the column to large extract from Halima's International Peace Prize acceptance speech in America. In the speech, the words 'horror', 'trauma', 'burning' keep recurring foiling and stressing the titular framing in the "victim's point of view". Lewis then offers his commentary and translation of her psycho-political position in the following terms:

Of course, she does not talk about revenge in her speech because it's not really palatable on an international stage, but revenge is the subtext of what she's talking about. For her, as for every other Darfuri victim I have spoken to, without justice there can be no reckoning, no homecoming, and no closure. I am a TV journalist and I filmed in Sudan over many years. I'm supposed to be an objective and impartial journalist, but if I was asked to give my films to the Criminal Court as evidence, I would do so even if that would be crossing the line.(Lewis, nd, p. 10-italics mine)

Lewis's interlocution of both Bashir's subtext and peace journalism avowed partiality not just construct a Darfurian diaspora and right to justice. His words predicate justice on revenge and eschew the politically correct language of international politics. They set the terms for self/other politics of conflict stimulation. So much for peace journalism! More specifically, his account speaks in the voice of all Darfurians objectifying and unifying their identities and setting himself as the rightful spokesman of their sufferings. This brings in a number of qualifications for Spivak's seminal queries and verdict on the subaltern: Can the subaltern speak outside the power-grid of her accommodation and co-optation? Can she unspeak the unspeakable nexus of her positioning and access structure? Can the subaltern unspeak the "unspeakable, thought, unspoken" of imperial politics through the circulatory grid of world-market-oriented literature of AngloAmerican publishing industry?

Spivak gives her negative answer for the subaltern sati to speak out on account of the latter's objectification in both White and Brown men's accounts?!The same answer qualifies for Arab African Sudanese woman immigrants of the metropolis. Their narratives are accommodated in World Literature and postcolonial politics in accordance with the 
power-dynamics inflected purposes. Their stories give access to the native harem - traditionally beyond the reach of Orientalists' penetration. Their accounts provide for instances of native-informant (authentic) voices (Spivak 1999). The latter can be only recuperated through the Western male subject and thus figures as the occasion for Western Self's subject conservation.

In the case of Tears of the Desert (2008), the circulation and canonization of the narrative provided Bashir with access for recognition, social inclusion, and enfranchisement within the metropolitan polity. They similarly provided the metropolitan circuit of hegemony with alibi for the neo-imperialist conquest of Africa and a voice for a native informant. This voice simultaneously exonerates the Western legacy of colonial suffering and fosters the quest for peace journalism with its bid for innocuous/ humanitarian story telling for metropolitan political purposes. Ultimately, Tears of the Desert (2008) showcases the distinction between subaltern visibility through language and voice in language, specifically in the context of the ardent quest (academic and else wise) to give the subaltern voice and center stage her presence.

\section{CONCLUSION}

\section{Subaltern Voice versus Visibility: Unspeaking Language Access Structure}

This paper tackled the question of the retrieval of subaltern Sudanese woman's voicing of Darfur's conflict. The paper engaged with unspeaking the language access structure and its ensuing problematic claim of giving the subaltern voice and visibility through language tailored to metropolitan powerpolitics. The paper utilized the grid structures in the Western translational composition of the Other and the circulation premise of World Literature. Instrumentalizing the emerging sociological turns in translation and literary studies, the paper examined the question of authorship/co-authorship of Tears of the Deserts: a Memoir of Survival in Darfur(2008) to read the poetics and politics enabling the text production, consumption and circulation in world literature and politics. The paper reached the following findings. First, the narrative is textually composed along the Afro-American women poetics of rememory with a mainstream nuance evident in the linearity of the narrative and progression of self-story. Second, this mainstream reworking of the oppositional thrust of rememory not only sets the narrative away from the circularity of trauma literature, but it also showcases the reworking of the publishing industry. The latter, governed by masculine ethos and global politics, is after the horror story that could sell as the new African Holocaust. Third, Bashir's account is framed in the holocaust meta-narrative and packaged through the authorial weight of the co-author, Damian Lewis. Third, Lewis, Bashir's White male interlocutor and savior, constructs Bashir's visibility through language and subjectposition in language through the intertwined textual grid of rememory and holocaust - enacted through the conceptual binary oppositional identity politics of Arab versus African. Fourth, this construction provides for Bashir's access structure and political enfranchisement in the UK and visibility through language. Finally, Bashir's voice and call for vengeance seal the lid on the Western legacy of African suffering to set the tone for the old-cum-new White Man's Mission-Burden of saving brown Darfurian women from brown Arab Sudanese man. The paper also shed lights on the distinction between the liable-to-be-spoken-of Sudanese security state atrocities and the unspoken-of affairs of neoimperial world politics - enacted through the contradictory parameter of Lewis' military-based peace journalism and poetics. Ultimately, the paper substantiates Spivak's verdict on the subaltern's aptitude to speak through a spotlight on metropolitan access structure that enable the subaltern's visibility through language, not her voice in language. After all, the subaltern cannot speak or exist in language except through the circuit of hegemonic powers' stakes. 


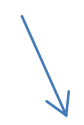

Fig. 1. A diagram showing the structural syntactic parallelism between the titular composition of Bashir's book and Conrad's Heart of Darkness

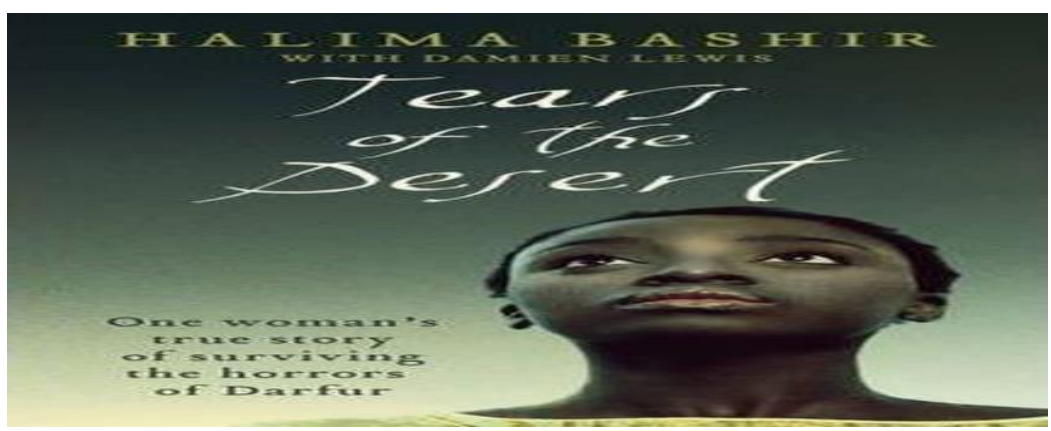

Fig 2. A book cover with the word horror at its ideological center. The type cast chosen and the girl figured at the center invoke the heart-shape of the horror of the seminal work on Africa-Heart of Darkness

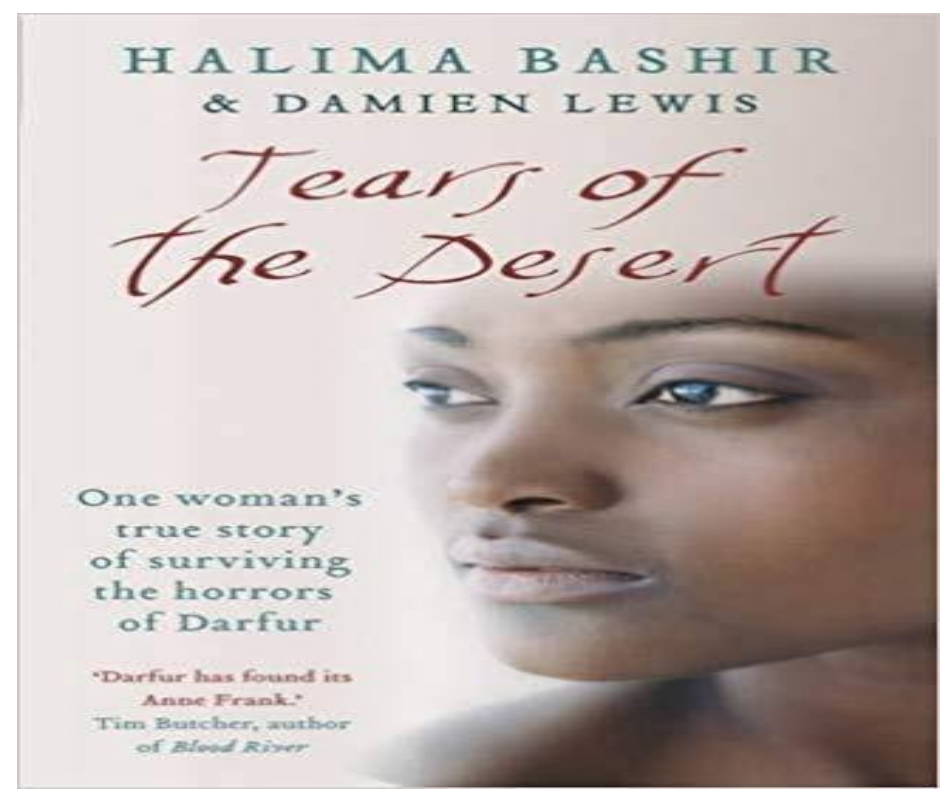

Fig 3. A book Cover in which Bashir's account and Darfur's crisis is framed along the Holocaust meta-narrative with Bashir poisoned as Darfur's Anne Frank 


\section{REFERENCES}

[1] Alex. W. (Apr. 2005) "Who Are the Darfurians? Arab and African Identities, Violence and External Engagement. "African Affairs Vol. 104, No. 415, pp. 181-205. Retrieved from

https://www.researchgate.net/publication/233756397_Who_a re the Darfurians Arab and African identities violence an d_external_engagement

[2] Angelelli, C. ([2014] 2016). Ed. The Sociological Turn in Translation and Interpreting Studies, 61 No 13. Retrieved from https://www.erudit.org/en/journals/meta/2016-v61-n3meta02995/1039233ar/

[3] Bashir, H. Lewis Damian (2008). Tears of the Desert: A Memoir of Survival in Darfur. New York: One World Ballantine Books.

[4] Bhabha, H. (1997). "The World and the Home". McClintock, A., Mufti, A. \&Shohat, E. (ed.), Dangerous Liaisons: Gender, Nation, \& Postcolonial Perspectives. Minneapolis: Minnesota University Press.

[5] Bourdieu, P. (1986). "Forms of Capital." Retrieved fromhttps://www.marxists.org/reference/subject/philosophy/ works/fr/bourdieu-forms-capital.htm

[6] Butcher, T. (2010) Blood River: A Journey to Africa's Broken Heart. Random House.

[7] Cordingley, A. Manning, C. (2017). "What is Collaborative Translation?" Collaborative Translation: From the Renaissance to the Digital Age.ED. Anthony Cordingley and Céline Frigau Manning. London: Bloomsbury.Retrieved from https://www.bloomsbury.com/us/collaborative-translation9781350006027/

[8] Damrosch, D. (2003). What is World Literature? Princeton, N.J: Princeton University Press.

[9] "Damian Lewis-Military Historians \& Authors." In Military Speakers: Real Heroes, Real Stories-in their own Words. Retrieved from http://www.militaryspeakers.co.uk/speakers/damien-lewis/

[10] Debian, R. (2019). "Multiple Rooms with Brought Down Walls: Aleppo's Holocaust and Democracy of/in the American Century." Cairo Studies in English Vol. 2. http://cse.journals.ekb.eg.

[11] --- (2017). "Packaging Zainab Al-Ghazali: The Gendered Politics of Translation and the Production of 'Moderate' Muslim Sister and Islamism." International Relations and Diplomacy. Vol. 5. No. 4.

[12] De Kock, 1. (1992). "Interview with Gayatri Chakravarty Spivak: New Nation Writers Conference in South Africa."ARIEL: A Review of International English Lit, 23:3, July. $\quad$ Retrieved from http://jan.ucc.nau.edu/ sj6/Spivak\%20Interview\%20DeKock. pd

[13] Engdahl, W. (2009).Full Spectrum Dominance: Totalitarian Democracy in the New World Order. Retrieved from https://archive.org/details/F.WilliamEngdahlFullSpectrumDo $\underline{\text { minance2009Scan }}$

[14] Anon. (n.d). "Habitus: Pierre Bourdieau." Social Theory rewired Retrieved from http://routledgesoc.com/category/profile-tags/habitus
[15] Hawas, M. Thoe D'haen. (2017). "Preface: What is World Literature -of Arabic." Brill: Journal of World Literature Vol.2

[16] Hermans, Theo. (2004). Translation in Systems: Descriptive and System-oriented Approaches Explained.

[17] Shanghai: Shanghai Foreign Language Education Press.

[18] Hirsch, M. (1994) "Maternity and Rememory." Motherhood and Representation. Ed. Donna Bassin, Margaret Honey, MeryleKaplan. Yale: Yale University Press.

[19] Lefevere, A. (1992). Translation, Rewriting and the Manipulation of Literary Fame. London: Routledge.

[20] ---. (1992). Ed. Translation/History/Culture: A Sourcebook. London: Routledge.

[21] ---(1999). "Composing the Other." Ed. Bassnett, Hirish. Postcolonial translation: Theory and Practice. London: Routledge.

[22] Lewis, D. (n.d). “A Victim's Point of View." Dialogue 9: International Justice: Pragmatism or Principle.Medicin Sans FrontieR. Retrieved from https://www.reddit.com/r/lifeisstrange/comments/3h...

[23] Lynch, J. (2015). "Peace Journalism: Theoretical and Methodological Development." Global Media and Communication. Vol.11. (3). pp. 193-199 Retrieved from https://journals.sagepub.com/doi/abs/10.1177/174276651560 6297

[24] Moretti, F. (2000)."Conjectures on World Literature.” Retrieved from https://newleftreview.org/issues/II1/articles/franco-moretticonjectures-on-world-literature

[25] Morrison, T. (1987). Beloved: A Novel. New York: Knopf.

[26] ----. (1988) "Unspeakable Things Unspoken: the AfroAmerican Presence in American Literature." TONI MORRISON THE TANNER LECTURES ON HUMAN VALUES Delivered atThe University of Michigan October 7, Retrieved

fromhttps://sites.lsa.umich.edu/mqr/2019/08/unspeakablethings-unspoken-the-afro-american-presence-in-americanliterature/

[27] ---. (2019) “'I wanted to carve out a world both culture specific and race-free': an essay by Toni Morrison.” The Guardian. Retrieved from https://www.theguardian.com/books/2019/aug/08/tonimorrison-rememory-essay

[28] Nazer, M., \& Lewis, D. (2003). Slave: My true story. New York: Public Affairs.

[29] Nur, H.S.M. (2014). "The Changing Statusof English Languagein Sudan." Issues in English Education in the Arab WorldCambridge: Cambridge Scholars Publishing Retrieved from https://www.slideshare.net/halasalih/the-changingstatus-of-english-language-in-sudan-5251423

[30] Anon. (1997) "Peace Journalism Option." Global Issues Social, Political, Economic and Environmental Issues That Affect Us All. Retrieved from https://www.globalissues.org/article/534/the-peacejournalism-option

[31] Tally, Jr. R (2014). "World Literature and its Discontent."English Language and Literature. Vol. 60. No. 
3.Retrieved

from

https://www.academia.edu/9442831/World_Literature_and_It s_Discontents

[32] Saeed, A. (2017). "A Review of Arabicization as a Controversial Issue of Language Planning in the Sudan.'Retrieved

from10.5539/ells.v7n2p144https://www.researchgate.net/publ ication/317258267_A_Review_of_Arabicization_as_a_Contr oversial Issue of Language Planning in the Sudan

[33] Wolf, M. (2009). "The Implications of a Sociological Turn methodological and disciplinary questions." Retrieved from.https://www.semanticscholar.org/paper/Theimplications-of-a-sociological-turn-\%E2\%80\%94-andWolf/cf4a1b2616b889fcf6d2bded2c71a77dd0e2a9d9

[34] ---. (2011). "Mapping the Field: Sociological Perspectives on Translation." International Journal of the Sociology of

i According to Hermans, Lefevere defined ideology as "the conceptual grid that consists of opinions and attitudes deemed acceptable in a certain society at a certain time, and through which readers and translators approach text" (qtd. from Hermans, 2004, p. 127).

ii Dambroush formulates world literature in terms of: all literary works that circulate beyond their culture of origin, either in translation or in their original language ... a work only has an effective life as world literature whenever, and wherever, it is actively present within a literary system beyond that of its original culture ... [World Literature] is a mode of circulation and of reading (Dambrosch 2003, p. 5)

This aspect of circulation and translation is particularly pertinent in the context of the asymmetrical power-relations between the culture of origin and global publishing industry of the text understudy. The Anglo-American publishing industry provides the access structure for circulation and integration into global literary system in accordance to Western subject conservation and power politics - a point that Lefevere partly takes in his thesis on translation as a refracted writing that compose the other in line of subject conservation and metropolitan Self construction

iiiIn Beloved (1987), Morrison gets the narrative main character, Sethe to use the word re-memory in place of the words remember and forget. Sethe uses the words "rememory" in the dual grammatical functioning as noun and verb. This coinage and resignification of the word re-memory poetically functions as an aesthetic scheme to engage with the cultural specificity of Afro-American women experience, whose parameter and double subjugation in Morrison's words maps the binaries of:

History versus memory, and memory versus memorylessness. Rememory as in recollecting and remembering as in reassembling the members of the body, the family, the population of the past. And it was the struggle, the pitched battle between remembering and forgetting, that became the device of the narrative (Morrison 2019 par 5)
Language.
No.
207:
$1-$ https://www.degruyter.com/view/journals/ijsl/2011/207/articl e-p1.xml

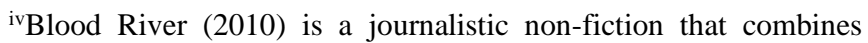
travelogue and history produced by a White male British journalist. The book deals with the political events in Congo and the metaphor "heart" features as the centerpiece for Western perception of Africa and universe of discourse through Africa is represented.

'In 2004, President Bush has used the term genocide with reference to Darfur as a pretext to impose economic blockade. The economic blockade was opposed by China on account of protecting her financial stakes, especially in the context of China current investment project in Africa. This neo-imperialist rivalry over the un-spoken of African oil-supplies was in much need of human face to communicate the Anglo-American stakes outside the oil paradigm. The media framing of Darfur's crisis was in need of a human voice and testimonials and hence the deployment of Bashir's account within the circuit of hegemony to redeem and frame the White Man's redefined mission of securing Anglo-American stakes against China. According to Engdahl (2009), Freedom Bush's Agenda (2005) has meant nothing except the instrumentalization and Weoponization of human rights in NATO led humanitarian intervention (Engdahl 2009). Literature and journalistic discourse becomes the new tactic for soft power military operation. The picture below is apopular icon where Darfur' crisis is given the label holocaust and constructed as a genocide.

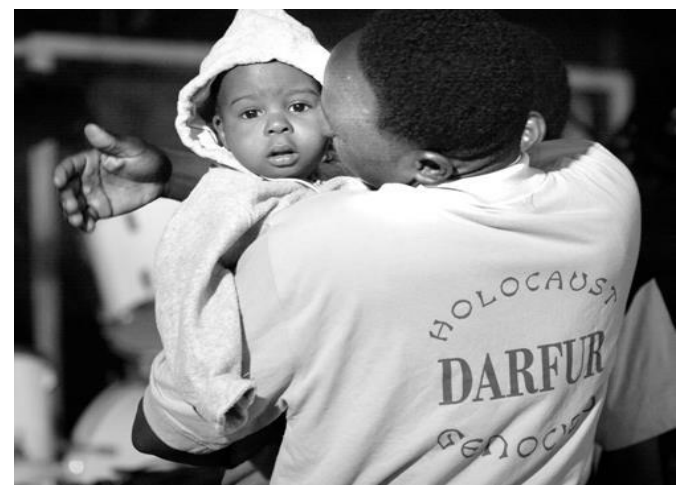

viIn Lewis's webpage, the same framing to his institutional credentials occur with his expertise in soft power military operation 
as a center piece for his authorial weight and power, especially in connection to non-Western world:

Damien Lewis is a number one bestselling author whose books have been translated into over forty languages worldwide. For decades he worked as a war and conflict reporter for the world's major broadcasters, reporting from across Africa, South America, the Middle and Far East and winning numerous awards. His books include the World War Two classics SAS Ghost Patrol, Churchill's Secret Warriors, The Nazi Hunters and Hunting the Nazi Bomb. Over a dozen of his books have been made, or are being made, into movies or TV drama series and several have been adapted as plays for the stage. $\mathrm{He}$ has raised tens of thousands of pounds for charitable concerns connected with his writing. https://www.damienlewis.com/

vii"Peace Journalism option"(1997) is the summary of the findings of the Conflict and Peace Journalism summer school (August 25-29 1997 Buckinghamshire, UK) over the week of August 25-29 1997. 